\title{
CELL WALLS AS TAXONOMIC MARKERS IN POLISH SPECIES OF THE GENUS ODONTOSCHISMA (DUM.) DUM. (HEPATICAE, CEPHALOZIACEAE)
}

\author{
JERZY SZWEYKOWSKI, KATARZYNA BUCZKOWSKA \\ Working Group for the Study of Genetic Variation in Bryophytes, \\ Department of Genetics, Adam Mickiewicz University, \\ ul. Szamarzewskiego 89, bld.C., PL 60-568 Poznań, Poland \\ e-mail: jeszweyk@main.amu.edu.pl (JS) and androsac@main.amu.edu.pl (KB)
}

(Received: September 22, 1998. Accepted: November 3, 1998)

\begin{abstract}
To get valuable diagnostic characters, the structure of cell walls was studied with use of two stains (Ruthenium Red -RRand Resorcine Blue - RB) and in polarized light. As far as the stem structure is concerned, European species of the genus Odontoschisma fall into two groups: in Odontoschisma elongatum and in Odontoschisma macounii a thick, frequently completely obscuring cell lumen, "lining layer" is present. It frequently, particularly after staining in RB, detaches from the rest of the cell wall. Such a layer is completely lacking in the two remaining species, viz. O. sphagni and $O$. denudatum. In polarized light only leaves of $O$. sphagni show a distinct bright border. The thin cellulose layer (bright in polarized light) embrace the angular thickenings in $O$. sphagni and $O$. denudatum, but is entering the inside of these thickenings in the two remaining species. Keys for determination of the four European species based on the staining properties of cell walls and their look in polarized light are provided.
\end{abstract}

KEY WORDS: staining, polarized light, Odontoschisma, Hepaticae, taxonomy, cell walls.

\section{INTRODUCTION}

Three of the four European species of the genus Odontoschisma occur in Poland (Szweykowki 1958, and unpublished data): Odontoschisma sphagni (Dicks.) Dum., Odontoschisma denudatum (Mart.) Dum. and Odontoschisma elongatum (Lindb.) Evans; the fourth European species of this genus, namely the arctic-alpine Odontoschisma macounii (Aust.) Underw. is - at present - unknown within the limits of the Polish state; its occurence, however, is plausible in the lime and mylonitic parts of the alpine zone of the Tatry Ridge. (Arnellia fennica another arctic-alpine, Ca tolerant species was discovered in the Tatry Range only recently Váña 1975, Szweykowski et al. 1993). Therefore we treat in the present paper all four European species.

One of the most important diagnostic characters in the European species of the genus Odontoschisma is the structure of the cell walls in the leaf blade, particularly with reference to wall thickening. In this respect, Odontoschisma sphagni (Fig. 1b) is unique: cell walls in plants of this species tend to be equally thickened in the marginal 1-2(3) cell rows usually forming distinct border, which is lacking altogether in the remaining three species. The cell wall thickening in the rest of leaf blade of the same species is restricted to the wall angles and are usually not bulging: their sides being for the most part concave; Odontoschisma elongatum, one of the remaining European species, differs from the others in its charac- teristic middle lamella: it is dark-stained and easily visible without use of any additional technique (Fig. 1c). The two other species, viz. Odontoschisma denudatum and Odontoschisma macounii show strong bulging trigones; they differ, according to literature data (eg., Müller 1954-1957, pp. 11181123 , Schuster 1974 p. 849), in relation of size of the trigones to the cell lumen: the trigones in Odontoschisma macounii (Fig. $3 \mathrm{~g}$ ) are usually rather large, frequently nearly as large as cell lumen, whereas the trigones in Odontoschisma denudatum, if they are typically developed, are much smaller. However, this differences is not always evident (see Schuster 1974 , p. 854) and sometimes even the reverse is true: the trigones in Odontoschisma denudatum can be larger that these in Odontoschisma macounii (Fig. 1a and d). The four species differ, of course, also in other characteristics (e.g. colour of the plants, kind of branching, ecology etc.); in spite of these differences, however, their proper identification is frequently difficult, and in various herbaria one rather frequently can find misidentified plants. The cell wall characteristics are usually the most reliable ones; however, one cannot infrequently find plants with rather weakly thickened walls (mod. leptoderma) where the mentioned differences vanish to a great extent.

In this situation we decided to use more precise methods to find more subtle differences, if any, in the structure of the cell walls. Therefore we performed staining with two different dyes and observed preparations in polarized light. 


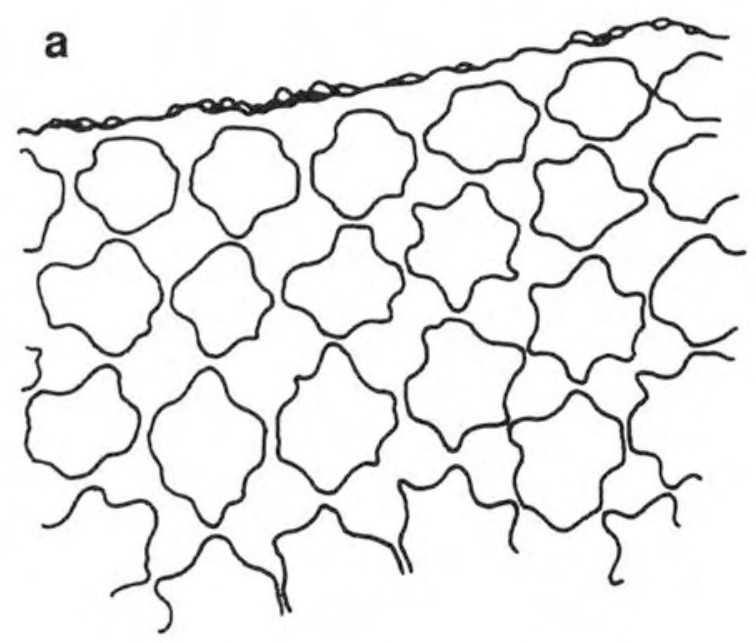

b

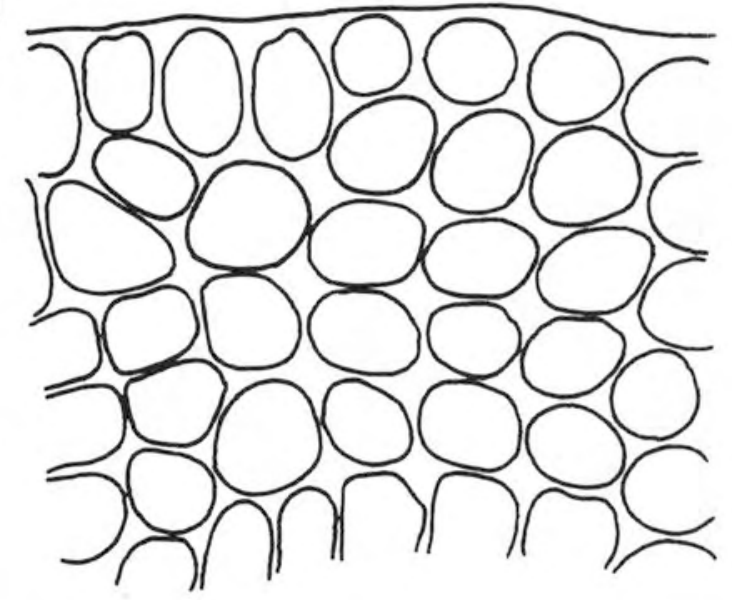

d

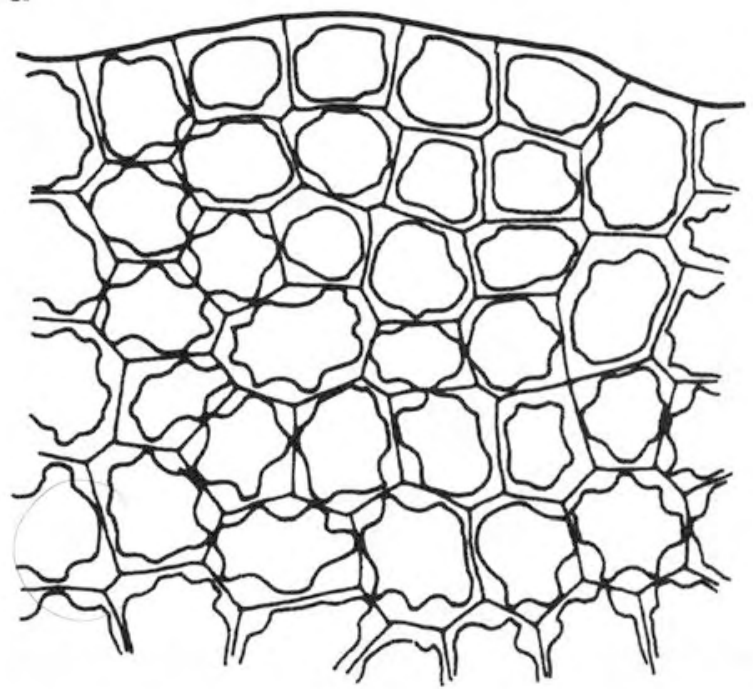

Fig. 1. Half-diagrammatic drawings of marginal parts of leaves: a) Odontoschisma denudatum (POZW 24372); b) O. sphagni (POZW 36163), c) O. elongatum (POZW 21849), d) O. macounii (POZW 13094).

\section{MATERIAL AND METHODS}

Living plants were brought to the laboratory in Poznan and then each sample was divided into two parts. One of them was put into culture in the glasshouse of the Genetics Department, and the other was preserved as the herbarium specimen. Both the cultures and the herbarium specimens have, of course, the same identification numbers (POZW). We used for our studies both living material from the cultures and the respective herbarium samples. As we have found no differences between staining results performed on living plants and on the respective herbarium samples, we decided - in order to raise the number of samples studied - to apply the same methods to several older herbarium samples; these, of course did not have counterparts in the culture.

We used two dyes in our studies: ruthenium red (RR), a stain for pectin substances and resorcin blue (RB), a specific stain for callose. Detached leaves and hand-made cross sections of stems were put into water solution of the proper dye for 15 minutes, (in the case of the weakly staining Odontoschisma denudatum longer, to get satisfactory results). After that time they were put into water and observed at various magnifications under an Olympus microscope. The best preparations were drawn with a camera lucida and photographed. Additionally, leaves and cross sections of stems of the same samples were observed under the microscope in polarized light.

\section{RESULTS AND DISCUSSION}

Stem

As descriptions of the stem structure in the European species of the genus Odontoschisma are rather vague, and some characteristic seem not to have been mentioned at all, we decided to describe the stem structure in more detail.

As far as stem cross sections are concerned, the European species of this genus form two rather distinct groups. The cells (as seen in stem cross sections) in Odontoschisma elongatum and in $O$. macounii are lined with a substance which stains intensively red purple with RR (Fig. 2b) but remains colourless in RB (Fig. 2c, e, f, g). This lining layer can frequently be enormously thick: it is uncommon for it nearly the whole cell lumen to be obscured (Fig. 2c, g). Interestingly 

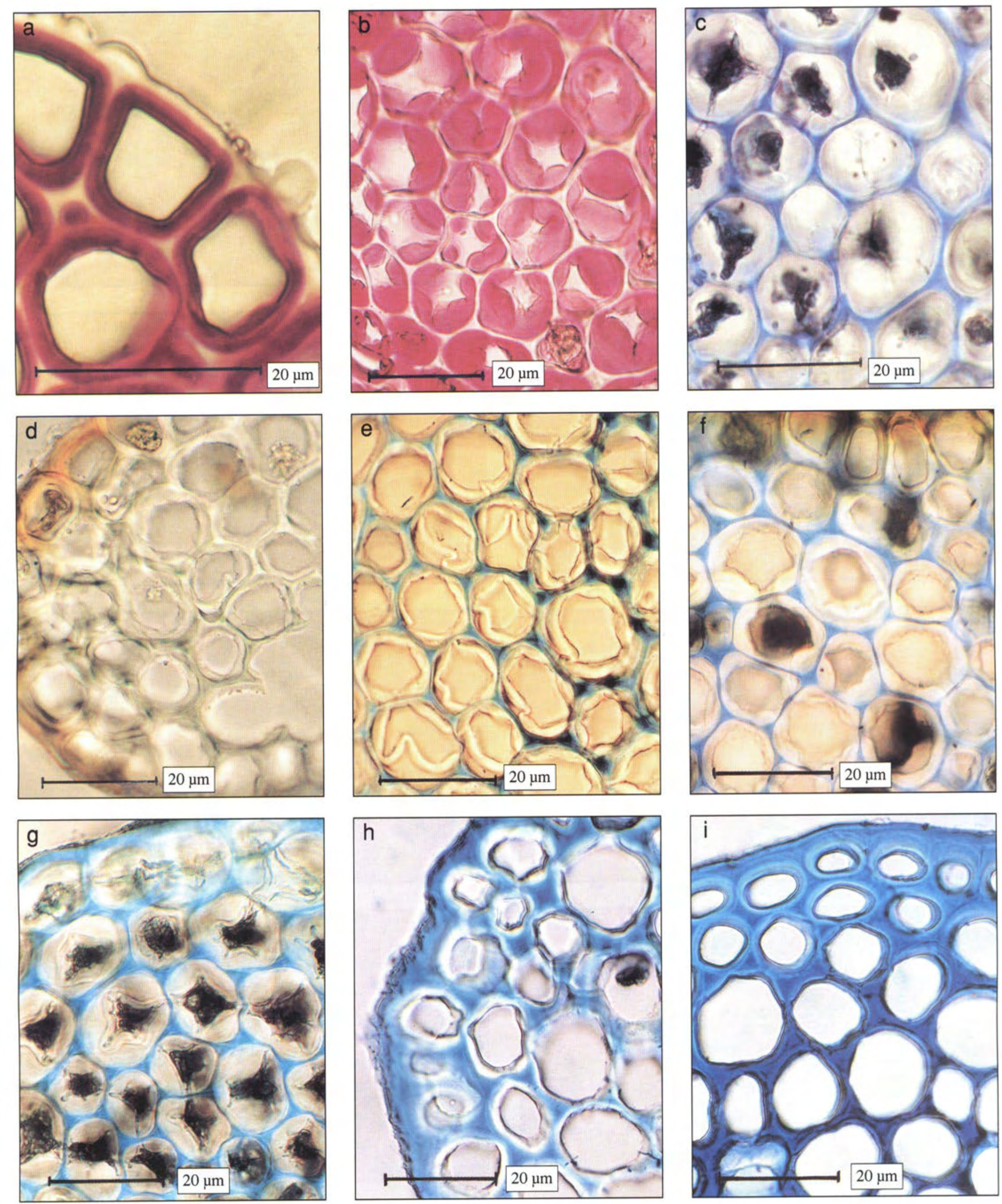

Fig. 2. a) part of a stem cross-section of Odontoschisma denudatum (POZW 35653) stained with RR; b) part of a stem cross-section of $O$. macounii (POZW 13090 stained in RR; c) the same stained with RB; d) part of a stem cross-section of O. elongatum (POZW 36512) unstained, showing the detached "lining layer"; e) the same, stained with RB, the "lining layer" is detached in many places; f) the same, another fragment; g) part of a stem cross-section of $O$. macounii (POZW 13090) stained with RB; h) part of a stem cross-section of $O$. denudatum (POZW 35653) stained with RB; i) part of a stem cross-section of $O$. sphagni (POZW 36700) stained with RB. 

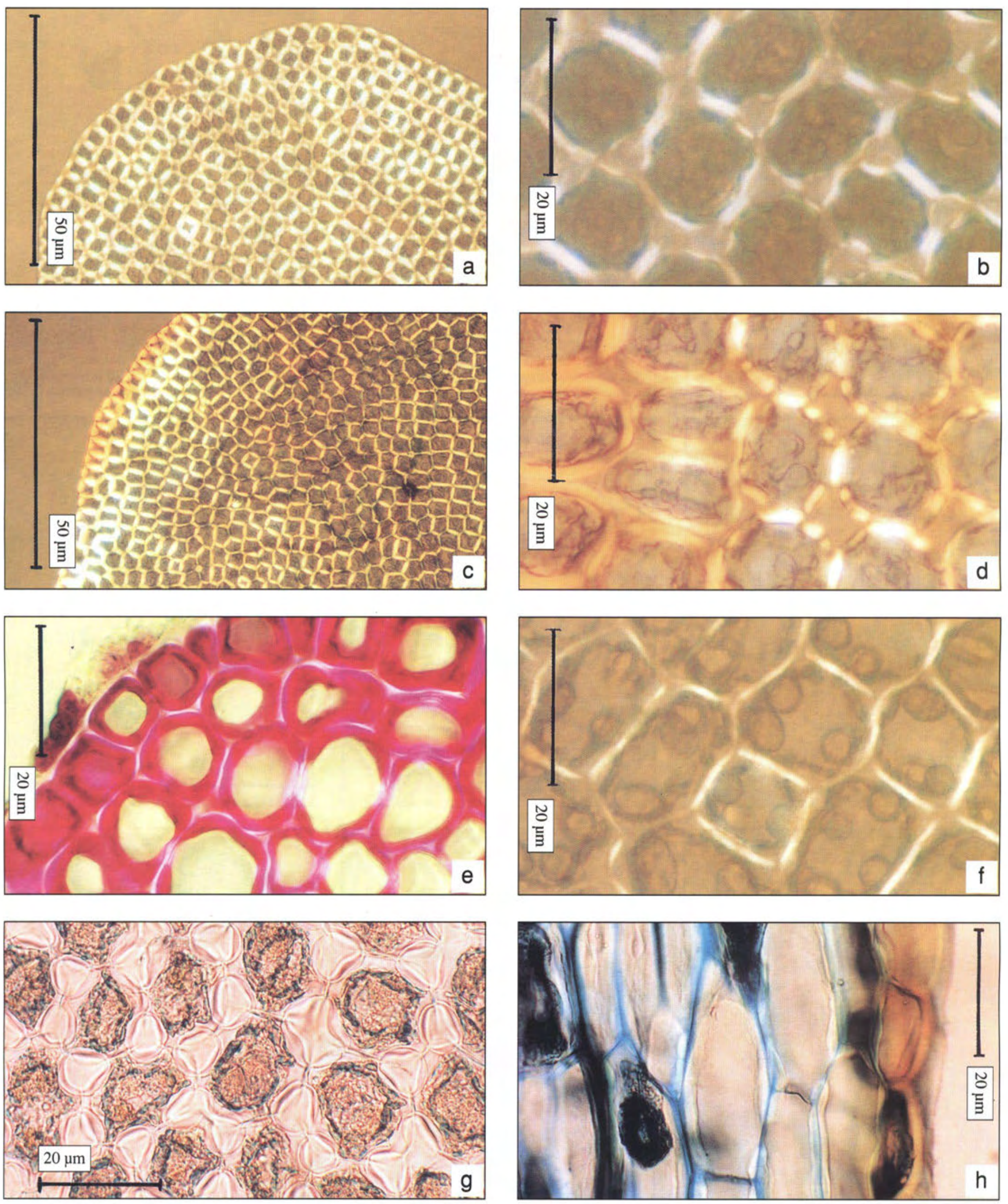

Fig. 3. a) leaf of Odontoschisma denudatum (POZW 36713) as seen in polarized light; b) the same, higher magnification; c) leaf of $O$. sphagni (POZW 36665 ) as seen in polarized light; d) the same, higher magnification; e) part of the stem cross-section in O.denudatum (POZW 35653) stained in RR photographed in polarized light; $\mathrm{f}$ ) leaf of $O$. elongatum (POZW 36512) as seen in polarized light; g) part of a leaf of $O$. macounii (POZW 13090) unstained, showing the angular thickenings; h) longitudinal section of a stem of $O$. elongatum (POZW 36512) stained in RB, showing the location of the "lining layer". 
enough, this layer is frequently detached from the wall proper (Fig. $2 \mathrm{~d}$ - unstained slide), even more often after the treatment with RB (Fig. 2e). The substance in question is deposited on the cell walls irregularly, which can be seen in stem longitudinal sections (Fig. 3h, Fig. 6). This is rather important for taxonomic purposes as one has to make several stem cross sections to be sure of the nature of the cell walls.

There is no trace of such a lining layer in the stems of the remaining two species, viz. $O$. sphagni and $O$. denudatum. As far as the last species is concerned (i.e. $O$. denudatum), its cell walls (we are still describing the stem cross sections) are, except for the middle lamella, completely red purple in RR (Fig. 2a). In RB, however, the middle lamella is intensively blue and the innermost parts of the cell walls, i.e. these bordering the cell lumen, are practically unstained (Fig. 2h). This innermost, whitish part of the cell wall does not form a distinct layer and it never detaches from the rest of the cell wall. One has only to compare micrographs (Fig. $2 \mathrm{f}$ and $\mathrm{h}$ ) to perceive the different nature of the cell walls in $O$. denudatum and $O$. elongatum.

Still a different picture is seen in Odontoschisma sphagni after treatment with RB. The whole cell wall (including the middle lamella) as observed in the stem cross sections is intensively stained blue; only the innermost parts of the cell walls (i.e. those bordering the cell lumen) are a bit less intensively stained, but it never, according to our observations, becomes whitish as in $O$. denudatum described above (Fig. 2i).

In stems of all the four species, the cellulose layer (bright in the polarised light) is situated between the middle lamella and the innermost (in relation to cell lumen), red stained in RR, part of the cell wall (Fig. 3e, Fig. 4).

We can sum up the observed differences in the form of the following key.

Key based on characters observed in stem cross sections

1. Lumina of most stem cells are lined with a usually thick layer, obscuring not infrequently the whole cell lumen; this layer stains intensively purplish-red in RR but remains completely colourless in RB Odontoschisma elongatum \& O. macounii

$1^{*}$. Lumina of stem cells are not lined with the substance described above. Cell walls become bluish in RB and stain rather weakly in RR Odontoschisma sphagni \& O. denudatum.

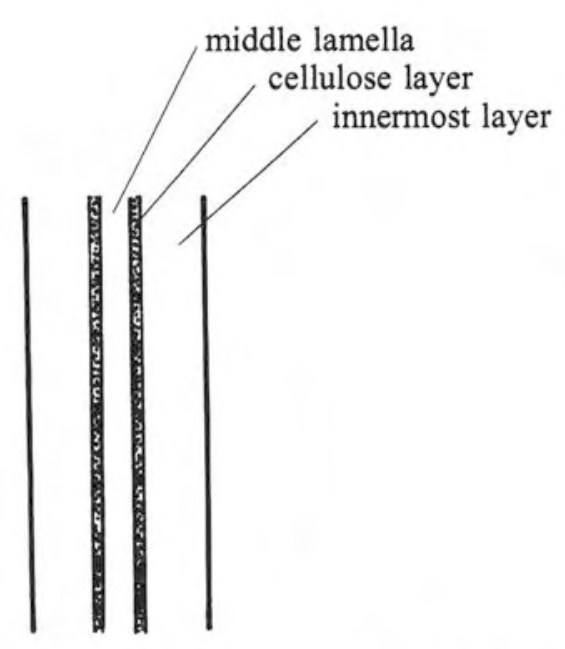

Fig. 4. Diagramm showing the structure of the cell wall in European species of the genus Odontoschisma, as seen in a longitudinal stem sections. The marked layer is bright in polarized light.

\section{Leaves}

Staining the leaves in toto gives no valuable taxonomically characters: the whole leaf blade is strongly stained either purplish red (in RR) or blue (in RB). However, on good (i.e. thin) cross sections of a leaf blade one can see, that the staining type is very similar to that observed in stems. But looking on the whole leaf, these staining differences vanish because of the masking effect of thick, heavily stained cell walls lying perpendicular to the objective-eyepiece axis.

In contrast, observation of leaf blades in polarized light gives interesting and taxonomically valuable results.

Under a low magnification (we used most frequently the lens $4 \mathrm{x}$ with an eyepiece $10 \mathrm{x}$ ) leaves of Odontoschisma sphagni differ distinctly from the remaining species. The leaf margins are distinctly brighter than the rest of leaf blades in this species (Fig. 3c). This bright margin is usually complete, i.e. it is seen around the whole leaf margin; but even when during the observation in normal (non-polarized) light the marginal cells are not markedly differentiated, which, at least in Poland, is rather frequently the case, the bright margin can be observed at least in some places in polarized light. Leaves of the remaining three species are equally bright (Fig. 3a), except for their basal parts, which are frequently darker than the rest of a leaf blade (Odontoschisma sphagni shows this dark basal part, too).

Observation under a higher magnification (we used usually an $40 \mathrm{x}$ lens and an 10x eyepiece) gives also valuable results. One can perceive here subtle, although very distinct differences between particular species. In Odontoschisma sphagni and $O$. denudatum the bright cellulose layer seems to be situated on the outer edges of the wall; this is particularly evident in the case of the angular thickenings: the bright strips embrace these thickenings and join with the fluorescent strips of the not thickened portions of the cell wall situated between the angular thickenings. In this manner a kind of a complete net is formed, which can be observed in the major parts of the blade. (Fig. 3d, Fig. 5b). Leaves of Odontoschisma denudatum look similar under the higher magnification. However, the net described above is less distinct here and is frequently broken (Fig. 3b, Fig. 5a).

A quite different picture emerges when one observes the leaves of Odontoschisma elongatum in polarised light (lens 40x and eyepiece 10x). Here, the bright, cellulose, strips enter the angular thickenings instead of running on their outer edges as is the case of the two previously discussed specie (Fig. 3f, Fig. 5c). It seems, that the leaf cell walls are of a similar structure to those of the stem cells. It looks as if the wall thickenings are made of the same substance as the lining layer of the stem cells described above.

Thus, the observation in polarized light allows the distinguishing of Odontoschisma sphagni from the rest of European species of that genus (bright leaf margins under low magnification) and Odontoschisma denudatum from Odontoschisma elongatum.

We will not interpret our findings in terms of the cell-wall chemistry. Rather, we try to use the described differences as reliable diagnostic markers in identifying doubtful plants; they could be especially important and useful for beginners because the classical differences are useful only after long training.

The results of our studies are summarised in Table 1 and Table 2.

The following key shows the possibility of using the described differences in identifying the four European species of the genus Odontoschisma. 


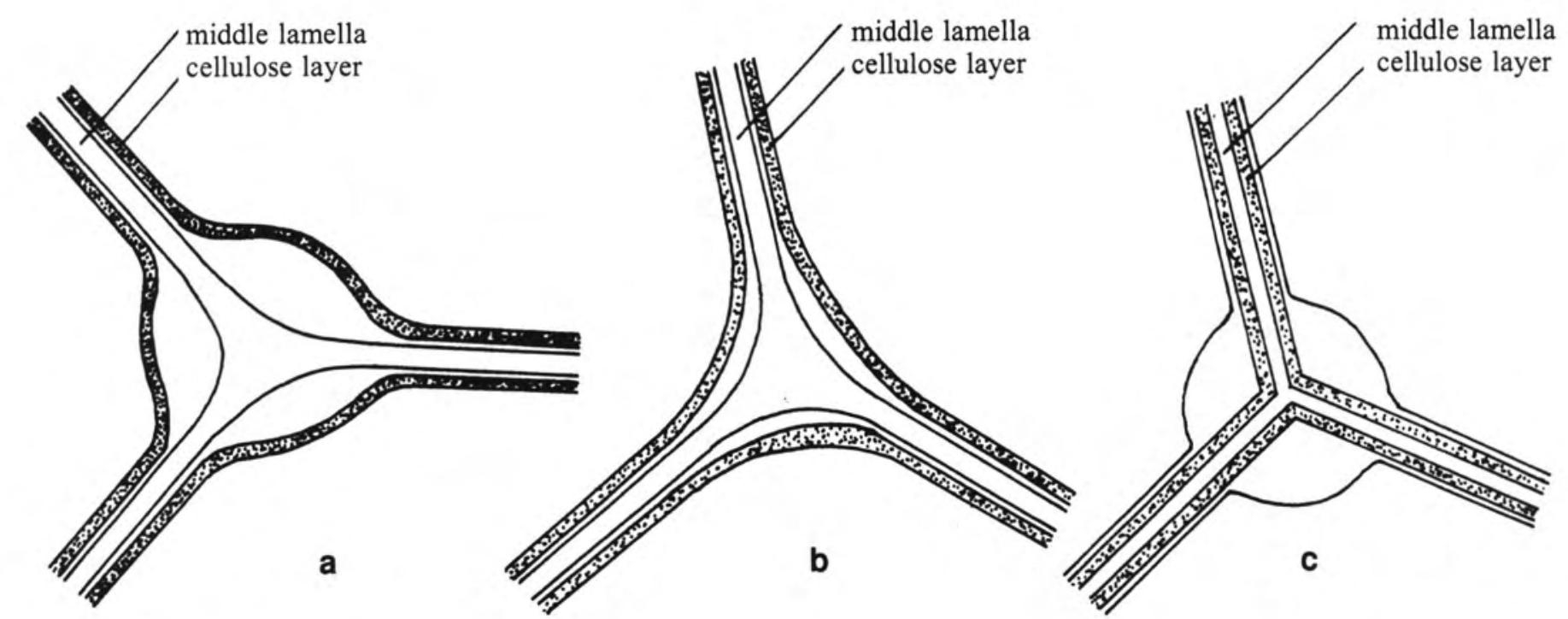

Fig. 5. Diagramms showing the situation of cellulose layer in leaves of the European species of the genus Odontoschisma; dark marked parts are bright in polarized light. a) Odontoschisma denudatum, b). O. sphagni, c) O. elongatum and $O$. macounii.

TABLE 1. Reaction of stem cross sections to particular treatments.

\begin{tabular}{l|l|l|l|l}
\hline Treatment & Odontoschisma sphagni & Odontoschisma denudatum & Odontoschisma elongatum & Odontoschisma macounii \\
\hline Ruthenium red 40x & $\begin{array}{l}\text { cortex strong red, medulla } \\
\text { less }\end{array}$ & $\begin{array}{l}\text { cortex strong red, medulla } \\
\text { less }\end{array}$ & $\begin{array}{l}\text { cortex \& medulla equally } \\
\text { red }\end{array}$ & $\begin{array}{l}\text { cortex \& medulla equally } \\
\text { red }\end{array}$ \\
\hline $\begin{array}{l}\text { Ruthenium red } \\
400 \mathrm{x}\end{array}$ & $\begin{array}{l}\text { outer parts of the wall red, } \\
\text { cuticle unstained }\end{array}$ & $\begin{array}{l}\text { outer parts of the wall red, } \\
\text { cuticle unstained }\end{array}$ & $\begin{array}{l}\text { outer parts of the wall red, } \\
\text { cuticle unstained }\end{array}$ & $\begin{array}{l}\text { outer parts of the wall red, } \\
\text { cuticle unstained }\end{array}$ \\
\hline $\begin{array}{l}\text { Resorcine blue } \\
400 \mathrm{x}\end{array}$ & $\begin{array}{l}\text { the whole wall blue, } \\
\text { cuticle blue }\end{array}$ & $\begin{array}{l}\text { only middle lamella and } \\
\text { cuticle blue }\end{array}$ & $\begin{array}{l}\text { only middle lamella and } \\
\text { cuticle blue }\end{array}$ & $\begin{array}{l}\text { only middle lamella and } \\
\text { cuticle blue }\end{array}$ \\
\hline Polarized light 40x & $\begin{array}{l}\text { cortex distinctly brighter } \\
\text { than medulla }\end{array}$ & $\begin{array}{l}\text { cortex \& medulla equally } \\
\text { bright }\end{array}$ & $\begin{array}{l}\text { cortex \& medulla equally } \\
\text { bright, but less intensively }\end{array}$ & $\begin{array}{l}\text { cortex \& medulla equally } \\
\text { bright, but less intensively }\end{array}$ \\
\hline Polarized light $400 \mathrm{x}$ & $\begin{array}{l}\text { bright (cellulose) layer } \\
\text { between middle lamella } \\
\text { and outer cell wall }\end{array}$ & $\begin{array}{l}\text { bright (cellulose) layer } \\
\text { between middle lamella } \\
\text { and outer cell wall }\end{array}$ & $\begin{array}{l}\text { bright (cellulose) layer } \\
\text { between middle lamella } \\
\text { and outer cell wall }\end{array}$ & $\begin{array}{l}\text { bright (cellulose) layer } \\
\text { between middle lamella } \\
\text { and outer cell wall }\end{array}$ \\
\hline
\end{tabular}

TABLE 2. Reaction of cell walls in the leaf blade to particular treatments.

\begin{tabular}{l|l|l|l|l}
\hline Treatment & Odontoschisma sphagni & Odontoschisma denudatum & Odontoschisma elongatum & Odontoschisma macounii \\
\hline Ruthenium red 400x & $\begin{array}{l}\text { middle lamella \& cuticle } \\
\text { remain unstained }\end{array}$ & $\begin{array}{l}\text { middle lamella \& cuticle } \\
\text { remain unstained }\end{array}$ & $\begin{array}{l}\text { middle lamella \& cuticle } \\
\text { remain unstained }\end{array}$ & $\begin{array}{l}\text { middle lamella \& cuticle } \\
\text { remain unstained }\end{array}$ \\
\hline Resorcine blue 400x & $\begin{array}{l}\text { middle lamella strong blue, } \\
\text { the rest faint blue }\end{array}$ & $\begin{array}{l}\text { middle lamella strong blue, } \\
\text { the rest faint blue }\end{array}$ & only middle lamella blue & only middle lamella blue \\
\hline Polarized light 40x & $\begin{array}{l}\text { margin bright, the rest } \\
\text { much less }\end{array}$ & $\begin{array}{l}\text { whole leaf blade } \pm \text { equally } \\
\text { bright }\end{array}$ & $\begin{array}{l}\text { whole leaf blade } \pm \text { equally } \\
\text { bright }\end{array}$ & $\begin{array}{l}\text { whole leaf blade } \pm \text { equally } \\
\text { bright }\end{array}$ \\
\hline Polarized light 400x & $\begin{array}{l}\text { bright strips on the outer } \\
\text { edge of angular } \\
\text { thickenings, "net" } \\
\text { unbroken }\end{array}$ & $\begin{array}{l}\text { bright strips on the outer } \\
\text { edge of angular } \\
\text { thickenings, "net" locally } \\
\text { broken }\end{array}$ & $\begin{array}{l}\text { bright strips enter the } \\
\text { angular thickenings, lying } \\
\text { close to the middle lamella }\end{array}$ & $\begin{array}{l}\text { bright strips enter the } \\
\text { angular thickenings, lying } \\
\text { close to the middle lamella }\end{array}$ \\
\hline
\end{tabular}

Key based on characters observed in leaves.

1. The outer margins of angular thickenings are bright in polarized light; their interiors remain dark. Middle lamella strongly blue in RB, the rest of the cell walls stains weaker (but still distinctively) becoming bluish.
2. Margins of leaf blades are much brighter in polarized light than the rest of the blade; angular thickenings usually concave-sided throughout Odontoschisma sphagni

$2 *$. The whole leaf blade is approximately evenly bright, at least its basal part remains dark; angular thickenings 


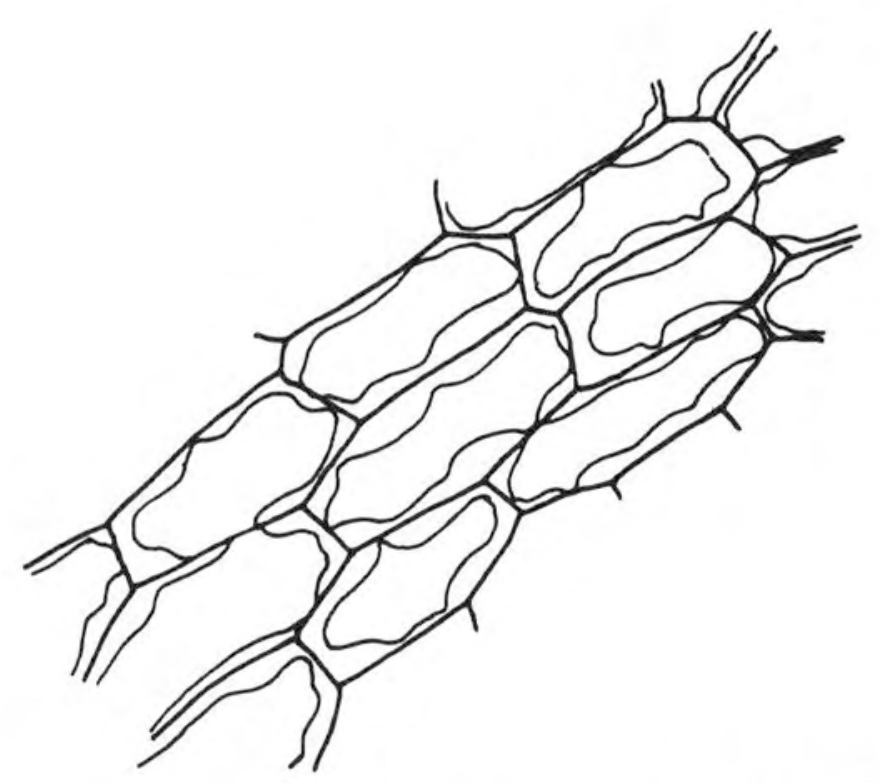

Fig. 6. Half-diagrammatic drawing showing the situation of the "lining layer" as seen in a longitudinal section of the stem of Odontoschisma elongatum.

usually (except in rare mod. leptoderma) distinctly to strongly bulging Odontoschisma denudatum

$1 *$. The outer margins of angular thickenings remain dark in polarized light, the bright strips entering bodies of the angular thickenings. Middle lamella stains blue in RB, the rest of the cell wall remains completely unstained 2 . Plants blackish, the middle lamella (without RB) usually brownish Odontoschisma elongatum

2*. Plants characterically whitish-green; middle lamella usually visible, but (without $\mathrm{RB}$ ) unstained Odontoschisma macounii.
In practice, these markers should be most useful in keeping apart Odontoschisma elongatum and Odontoschisma denudatum, especially in cases, when the latter species does not form the characteristic flagelliform gemma-bearing shoots, which is not uncommon, at least in Poland.

\section{AKNOWLEDGEMENTS}

The costs of the field work were paid partially by funds provided by the Polish Committe of Scientific Research (KBN: grant No. 409729101 for the period 1992-1994, and grant No. 406/PO4/95/08 for the year 1995-1998). We aknowledge this support very much, without it the work could not be completed.

Our warmest thanks are due also to Professor Adam Woźny, from the Depatment of General Botany at the Adam Mickiewicz University for his help in perfoming staining of the stem sections.

\section{LITERATURE CITED}

MÜLLER K. 1954-1957. Die Lebermoose Europas, 3. Aufl., Akademische Verlagsgesellschaft Geest \& Portig K.-G., Leipzig. p. 1365.

SCHUSTER R.M. 1974. The Hepaticae and Anthocerotae of North America, east of the Hundredth Meridian, Vol. III, Columbia University Press, New York and London, p. 880.

SHLJAKOV R.N. 1979. Pieczienocznyje mchi sjeviera S.S.S.R., t. 2 Lofoziewyje, (Hepatics of the northern territories of the USSR, vol. 2, Lophoziaceae) Nauka, Leningrad, p. 191 (in Russian).

SZWEYKOWSKI J., KOŹLICKA M., BUCZKOWSKA K., CHUDZIŃSKA E., BARCZAK H. 1993. Arnellia fennica (Hepaticae, Arnelliaceae) rediscovered in the Tatras, Fragm. Flor. Geobot. Suppl. 2(1): 323-329.

SZWEYKOWSKI J. 1958. Prodromus Florae Hepaticarum Poloniae, Prace Kom. Biol. PTPN 20: 1-600.

VÁŇA J. 1975. Arnellia fennica (Hepaticae) v Karpatach, Preslia 47(1): 93-94.

\section{ŚCIANA KOMÓRKOWA JAKO CECHA DIAGNOSTYCZNA U ŚRODKOWOEUROPEJSKICH GATUNKÓW RODZAJU ODONTOSCHISMA (DUM.)}

\section{STRESZCZENIE}

W celu uzyskania pewniejszych niż dotychczas cech diagnostycznych zbadano reakcję ścian komórkowych łodyżki (na przekrojach poprzecznych) oraz liści czterech europejskich gatunków rodzaju Odontoschisma na barwienie czerwienią rutenową (RR) i lakmoidem (RB). Obserwowano także przekroje poprzeczne łodyżek oraz wypreparowane liście w świetle spolaryzowanym. Znaleziono wyraźne różnice, które pozwoliły na konstrukcję oryginalnych kluczy do oznaczania.

SŁOWA KLUCZOWE: wątrobowce, Odontoschisma, taksonomia, ściana komórkowa, barwienie, światło spolaryzowane. 